\title{
CENA VIVA: POESIA E TEATRO EM FERNANDO PESSOA
}

\author{
Maria Ester Maciel \\ Universidade Federal de Minas Gerais
}

Para Mónica Serra

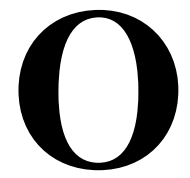

escuro domina o palco, com exceção apenas de um spot que ilumina um pequeno móvel encostado na parede à direita. O foco de luz se dirige para o espelho imediatamente ao lado, deixando explícita a imagem de um homem que acaba de vestir seu smoking. Ele tem uma expressão congelada, nada em seus olhos reluz. De repente o espaço daquilo que se assemelha a um quarto de hotel fica inteiramente iluminado. O homem se penteia, cuidadoso. Num gesto sem ênfase, desvia o olhar para o relógio dependurado na mesma parede do espelho. São sete e cinqüenta da noite. Com passos lentos, dirige-se ao outro lado do quarto, abre o armário e pega uma garrafa de champanhe que coloca sobre a mesa ao lado. Volta ao armário. Tira cinco pequenos frascos e coloca-os junto da garrafa. Vai mais uma vez ao armário e pega um cálice de cristal. Abre, discretamente, a garrafa. Despeja a bebida no cálice e nela mistura o pó contido nos frascos. Com a taça em uma das mãos, vai até o espelho. Alonga o corpo, com elegância, fixa o olhar em sua própria imagem e bebe o líquido, degustandoo. Ligeiramente entorpecido, vai até a cama e se deita, com a altivez de quem não tem nada a perder. São oito horas em ponto. O quarto escurece. Um spot ilumina a porta que se abre. Entra outro homem. A luz cai, em resistência, sobre o rosto do homem deitado.

Homem que chega: "O que houve, dói-lhe a cabeça?"

Homem deitado: "Não. Acabei de tomar cinco frascos de arseniato de estricnina. Fique aqui. Quero que assista à minha morte." 
O que se segue é previsível: a morte convulsiva do personagem que, na realidade, não é senão o poeta português Mário de SáCarneiro, que, em 1916, suicidou-se de maneira teatral, em presença do amigo José Araújo, aos vinte e seis anos de idade, no Hotel Nice, em Paris, depois de ter anunciado várias vezes a Fernando Pessoa, por carta, o seu intento suicida.

Ao transformar a própria morte em espetáculo, Sá-Carneiro que vivera entre a atmosfera decadentista do fim do século XIX e a efervescência vanguardista da primeira década do século XX levou ao extremo um dos principais lemas do seu tempo: o de converter a vida em arte. Ator e artífice de si mesmo, já colocava em cena, naquela época, uma concepção de teatro que Antonin Artaud defenderia mais tarde: a do teatro enquanto encenação que "carrega em si tanto sua finalidade quanto sua realidade" e que se configura como "um meio refinado de compreender e exercer a vida" 1 Teatro que, sem se colocar a serviço de um enredo e de um diálogo preconcebidos, se apresenta ele mesmo enquanto linguagem à medida em que vai se constituindo aos olhos do espectador.

Sá-Carneiro, antes mesmo do ato performático de sua morte, já atentara para a importância do teatro enquanto uma linguagem específica que, longe de ser um mero ramo acessório da linguagem verbal, é capaz de redimensionar a própria linguagem literária, levando-a a assumir-se enquanto corpo que se encena a si mesmo, que se desvia dos significados para os sentidos e se furta às funções utilitárias a que se vê impelida pelo uso convencional. Essa atenção se faz ver não só em vários poemas, contos e peças que escreveu, mas, sobretudo, na novela $A$ confissão de Lúcio, onde a teatralização da linguagem, das personagens, do narrador e da narrativa se radicaliza ao ponto de se configurar como uma espécie de script metafórico da cena viva que constituiria o suicídio do autor.

Esse apreço à teatralização da vida e da literatura, que remonta inegavelmente ao movimento romântico (sobretudo em suas

${ }^{1}$ ARTAUD. O teatro e seu duplo, p. 4. 
vertentes inglesa e alemã), vai aparecer de forma semelhante, mas também muito distinta, em Fernando Pessoa, que, dois anos antes da morte de Sá-Carneiro, já tinha criado (em atmosfera também performática, segundo relata a Adolfo Casais Monteiro, na famosa carta de 1935), o seu universo heteronímico. Ainda que, como o amigo, Pessoa se transfigure em uma persona poética e introduza na sua obra escrita aspectos inerentes à esfera da encenação teatral, somando a isso um expresso interesse pela arte dramática, sua relação vivencial com esta não foi tão explícita quanto a de SáCarneiro. Ou seja, ele não incorporou essa arte à sua vida civil, biográfica, ao ponto radical de converter-se, ele mesmo, em um espetáculo vivo. Preferiu dar realidade a seus outros de papel e atuar através, com e sob eles. Suportar a existência através do jogo. Ficcionalizar-se na mesma proporção em que dava realidade e autonomia às suas personagens.

Tanto Sá-Carneiro quanto Pessoa tiveram uma relação criativa com a idéia de teatro, no sentido de "encenação" liberta das amarras do discurso. Foi o que permitiu ao primeiro exercitá-la como um ato e ao segundo dar uma existência extratextual aos seus heterônimos, mesmo os tendo criado através do exercício da palavra. Índice da abertura de ambos para a exploração intensa da potencialidade que a poesia tem de dialogar com outras artes.

Quando Fernando Pessoa cria o Sensacionismo, corrente que atribui ao poeta a tarefa de captar a realidade através de sensações múltiplas e simultâneas, passando-as pelo filtro do entendimento e da palavra, ele busca em outras artes, como a pintura cubista, o teatro e a música, subsídios para sua teoria. O interseccionismo, uma das vertentes do Sensacionismo, pressupõe a espacialização do poema, compreendido enquanto um topos móvel de entrecruzamento e sobreposição reversíveis de planos, linguagens, imagens, realidades, como se pode ver não apenas no poema Chuva Oblíqua, onde o teatro aparece explicitamente como tema especial da sexta parte, mas também na própria constituição do conjunto da obra pessoana. Esse trânsito em vários territórios justifica, em certa 
medida, a maleabilidade estética do autor, a capacidade que sempre teve de incorporar alteridades cada vez mais outras e mais suas. Justifica, portanto, a sua incorporação inventiva dos signos teatrais, visível principalmente no que se pode chamar de estética do fingimento, base de sua concepção de poema e de sujeito poético.

A idéia de "drama-em-gente", lançada por Pessoa como uma suposta pista para se entender sua obra, advém dessa estética que confere ao poeta o atributo de fingidor. Em parte mantendo uma secreta afinidade com o que Valéry chamou de "teatro mental", espécie de "mise-en-scéne" da subjetividade, essa noção indicia uma cumplicidade visceral do autor com o que designou, em um ensaio teórico sobre o drama, de "instinto cênico", força motriz do ato moderno de criação poética que ele mesmo deflagra em sua obra e que implica no exercício sincero de subjetividades postiças, já que, nesse caso, o fingimento não deixa de ser a expressão de uma sinceridade estética. Daí ele se definir como um poeta dramático por excelência, que "nunca teve uma só personalidade, nem pensou nunca, nem sentiu, senão dramaticamente, isto é, numa pessoa, ou personalidade, suposta, que mais propriamente do que ele próprio pudesse ter esses sentimentos". ${ }^{3}$ O dramático, nesse caso, furta-se à condição estereotipada de "gênero" literário, para se configurar no plano mais amplo da encenação e para ser também uma espécie de exercício de otredad, visto que, como observa José Augusto Seabra, em seu trabalho precursor sobre as relações entre poesia e teatro na obra do poeta português, "o que se nos revela, precisamente, de mais original em Pessoa é o paradoxo aparente de enquanto poeta lírico, que ele é por natureza intrínseca, assumir no seu lirismo uma forma dramática, sem que a sua obra se vaze no gênero 'drama'"4 .

2 PESSOA. Obras em prosa, p. 277.

${ }^{3}$ PESSOA. Obras em prosa, p.82.

${ }^{4}$ SEABRA. Fernando Pessoa ou o poetodrama, p. XIX. 
São muitos os ensaios, cartas ou fragmentos pessoanos dedicados à reflexão sobre a questão do "drama", no sentido que ele deu a esse termo. Em quase todos, o jogo dialógico entre poeta lírico e poeta dramático aparece, ainda que às vezes tensionado por uma outra categoria, mais atópica (e talvez, mais iluminadora), de "dramático sem poeta”, que escapa às definições previsíveis, por estar fora do registro meramente literário. Na carta de 1931, dirigida a João Gaspar Simões, por exemplo, Pessoa diz:

Sabe que, como poeta, sinto; que, como poeta dramático, sinto despegando-me de mim; que, como dramático (sem poeta), transmudo automaticamente o que sinto para uma expressão alheia ao que senti, construindo na emoção uma pessoa inexistente que a sentisse verdadeiramente, e por isso sentisse, em derivação, outras emoções que eu, puramente eu, me esqueci de sentir ${ }^{5}$.

Está aí implícito, a meu ver, o paradoxo que pode elucidar o que o próprio Pessoa chamou de "poeta fingidor": um poeta que não é poeta lírico nem dramático, mas é os dois ao mesmo tempo e outra coisa: um dramático (sem poeta). Essa outra coisa poderia ser associada ao referido "instinto cênico", que seria o elemento por excelência do teatro, compreendido fora do domínio exclusivo do texto escrito. É nessa medida que Pessoa mantém uma relação não convencional com a arte teatral: ele valoriza predominantemente o que nela existe de intrínseco, de não condicionado pelo conceito de "peça" ou de "poema dramático", e que, transposto para o universo literário, pode conferir a este uma nova dimensão.

Isso não significa que ele não tenha explorado também, como escritor, o chamado "gênero dramático", não só na composição de sua heteronímia (ainda que nesta predomine o "dramático" sem gênero), como também na construção de textos denominados de dramáticos pelo próprio autor, como Na floresta do albeamento, $O$ marinheiro e Primeiro Fausto. Mas, como é previsível, em se tratando de Pessoa, mesmo esses textos não se adequam perfeita-

${ }^{5}$ PESSOA. Obras em prosa, p. 66. 
mente ao que se espera de um poema dramático, no sentido tradicional.

O primeiro, Na floresta do albeamento, é um monólogo em prosa, que, em meio a uma atmosfera de irrealidade, encerra uma voz sonâmbula não dizendo nada que não seja ela mesma, visto que o eu que a pronuncia encontra-se num estado paradoxal de "torpor lúcido, pesadamente incorpóreo, estagno, entre um sono e a vigília, num sonho que é uma sombra de sonhar". 6 É um drama por subtração, ou que nem chega a ser, pela extrema volatilidade com que se configura aos olhos e aos ouvidos do leitor.

Já O marinheiro apresenta uma aparente forma de texto dramático: existem personagens em diálogo, cenário e alguns artifícios de sugestivo caráter teatral. Mas inexiste a ação, e o tempo referenciável é completamente abolido. O que se vê são três mulheres sem corpo, velando uma mulher morta (que, segundo ele, "finge estar ali") e conversando sobre sonhos e memórias de um passado que não houve. O marinheiro, que dá título à peça, não passa de um personagem do sonho de uma delas. E todas, no final, chegam a dizer serem apenas o sonho desse marinheiro sonhado. Pessoa caracteriza esse poema como um "teatro estático", definido como "aquele cujo enredo dramático não constitui ação - isto é, onde as figuras não só não agem, porque nem se deslocam nem dialogam sobre deslocarem-se, mas nem sequer têm sentidos capazes de produzir uma ação". ${ }^{7}$ E como aponta José Augusto Seabra, "não parece sequer que Pessoa tenha concebido este drama como representável: ele destina-se mais a ser lido do que a ser visto, ou antes a ser visualizado através das palavras". 8

Quanto ao "Primeiro Fausto", composto inteiramente em versos, não há cenário nem enredo, e a identidade de quem enuncia

\footnotetext{
${ }^{6}$ PESSOA. Obra poética, p. 603.

${ }^{7}$ PESSOA. Obra em prosa, p.283.

${ }^{8}$ SEABRA. Fernando Pessoa ou o poetrodrama, p.28.
} 
mal se define. É, na verdade, um longo poema lírico, de inegável tensão dramática, que ao mesmo tempo se apresenta como um conjunto fragmentado de pequenos poemas avulsos, distribuídos em quatro temas e dois diálogos. Uma tentativa inacabada de se construir um drama faustiano que deveria se desdobrar em mais duas grandes composições, mas que, apesar disso, ou por isso mesmo, se realiza perfeitamente enquanto construção poética, chegando a se configurar também como espaço de confluência de vozes fragmentadas que remetem aos vários heterônimos pessoanos.

Essa ruptura com a tipologia tradicional do texto dramático, constatável em todos esses escritos, não atende, necessariamente, a qualquer outro modelo instituído (moderno ou não), mas faz parte de uma concepção própria, de caráter paradoxal, de arte dramática, desenvolvida pelo poeta em toda a sua obra. Paradoxal, porque também se entrecruza com um conceito igualmente peculiar de lírica e de sujeito poético, se considerarmos os poemas e os ensaios pessoanos em que este entrecruzamento se explicita.

De qualquer forma, pode-se detectar em todo esse universo de máscaras, vozes e linguagens, uma maneira nova de se incorporar à poesia elementos da esfera teatral, sem que nem a poesia nem o teatro se anulem enquanto especificidades estéticas, mas se redimensionem reciprocamente, ao mesmo tempo dentro e fora do território verbal. Isso, porque a própria trilha poética inaugurada por Pessoa também escapa aos lugares-comuns da lírica compreendida sob o prisma dos gêneros.

Como o fez, também, de maneira diferente, Mário de SáCarneiro, ao exercitar, tanto na vida quanto na obra, a proposição de Artaud, segundo a qual "o teatro se confunde com suas possibilidades de realização quando delas se extraem as conseqüências poéticas mais extremas".?

${ }^{9}$ ARTAUD. O teatro e seu duplo, p. 39. 


\section{Referências Bibliográficas}

ARTAUD, Antonin. O teatro e seu duplo. Trad. Teixeira Coelho. São Paulo: Martins Fontes, 1993.

COHEN, Renato. Performance como linguagem. São Paulo: Perspectiva, 1989.

GLUSBERG, Jorge. A arte da performance. Trad. Renato Cohen. São Paulo: Perspectiva, 1987.

PESSOA, Fernando. Obras em prosa. Rio de Janeiro: Nova Aguilar, 1982.

PESSOA, Fernando. Obra poética. Rio de Janeiro: Nova Aguilar, 1981.

SÁ-CARNEIRO, Mário de. Obra completa. Rio de Janeiro: Nova Aguilar, 1995.

SEABRA, José Augusto Seabra. Fernando Pessoa ou o poetodrama. São Paulo: Perspectiva, 1982.

\section{Resumo}

Este ensaio investiga as relações entre poesia e teatro na obra de Fernando Pessoa, com vistas a mostrar como o poeta português cria uma maneira nova de incorporar à poesia elementos da esfera teatral, sem que nem a poesia nem o teatro se anulem enquanto especificidades estéticas, mas se redimensionem reciprocamente, dentro e fora do território verbal.

\section{Resumen}

Este ensayo investiga las relaciones entre poesía y teatro en la obra de Fernando Pessoa, con el propósito de mostrar como el poeta portugués cria un nuevo modo de incorporación a la poesía de varios aspectos de la esfera teatral, sin que ni la poesía ni lo teatro se anulen como especifidades estéticas, sino que se redimensionen reciprocamente, dentro y fuera del territorio verbal. 